\title{
HUBUNGAN KEPUASAN KERJA, STRES GURU \\ DENGAN KEBAHAGIAAN GURU PENDIDIKAN AGAMA SEKOLAH MENENGAH DI KOTA AMBON
}

\author{
Donny Toisuta \\ donny_toisuta@yahoo.com \\ Program Studi Magister Manajemen Pendidikan \\ FKIP-Universitas Kristen Satya Wacana
}

J.T Lobby Loekmono

lobby.loekmono@staff.uksw.edu

Program Studi Bimbingan dan Konseling

FKIP-Universitas Kristen Satya Wacana

\begin{abstract}
ABSTRAK
Masalah penelitian dirumuskan: (1) Adakah hubungan yang positif dan signifikan antara kepuasan kerja dengan kebahagiaan guru pendidikan agama sekolah menengah di kota Ambon? (2) Adakah hubungan yang negatif signifikan antara stresguru dengan kebahagiaan guru pendidikan agama sekolah menengah di kota Ambon? Subjek penelitian berjumlah 117 orang guru agama sekolah menengah dari 5 kecamatan di kota Ambon. Kebahagiaan diukur dengan Authentic Happiness Inventory (AHI)) dari Seligman, Kepuasan Kerja guru diukur dengan Teacher Job satisfaction Questionnaire dari Lester dan Stres Guru diukur dengan Angket Stres Guru yang dikembangkan oleh Kyriacou. Hasil penelitian menunjukkan: (1) Ada hubungan positif signifikan antara kepuasan kerja dengan kebahagiaan guru pendidikan agama sekolah menengah di kota Ambon dengan $\mathrm{p}$ $=0,014<0,05 ;$ (2) Ada hubungan yang negatif dan tidak signifikan antara stres guru dengan kebahagiaan guru pendidikan agama sekolah menengah di kota Ambon dengan $r x y=-0,137$ dan $p=0,070>0,05$.
\end{abstract}

Kata Kunci: kepuasan kerja, stres guru, dan kebahagiaan

\section{PENDAHULUAN}

Seligman (2005) mengungkapkan bahwa kunci kebahagiaan adalah ketika manusia mampu memaknai setiap proses hidupnya secara positif. Pendapat Seligman (2005) sejalan dengan Veenhoven (2001) menyatakan bahwa kebahagiaan berhubungan dengan seberapa individu menikmati hidupnya secara keseluruhan. Kebahagiaan juga melibatkan kepuasan (kepuasan secara umum dan pada ranah kehidupan yang spesifik), afeksi yang menyenangkan dan rendahnya afeksi negatif.

Dalam dunia pendidikan, menurut Garrett (dalam Ouyang dan Paprock, 2009) guru dianggap sebagai sumber yang kuat untuk mengembangkan kualitas sekolah, namun kepuasan kerja guru jarang dipandang penting. Kepuasan kerja guru merupakan salah satu faktor penentu dalam kualitas guru, dari segi stabilitas pengajaran dan komitmen sebagai pengajar di sekolah. Kontribusi kepuasan kerja guru tidak hanya untuk motivasi dan perbaikan kualitas guru, tetapi juga untuk belajar dan pengembangan 
peserta didik. Peneliti di Amerika sejak pertengahan abad 20, telah menempatkan perhatian ke topik tentang kepuasan kerja, tetapi hanya sebagian kecil dari mereka yang fokus pada kepuasan kerja guru. Profesi guru sebenarnya sangat rentan mengalami ketidakpuasan dalam bekerja serta stres guru yang menyebabkan hilangnya kebahagiaan (Ouyang dan Paprock, 2009).

Penelitian Holle (2009) pada 36 SD Swasta di kota Ambon dengan populasi 205 orang guru dan sampel sebanyak 127 orang guru menemukan hasil bahwa kepuasan kerja guru memiliki hubungan yang positif dan signifikan dengan Kebahagiaan guru $\left(\mathrm{r}_{\mathrm{xy}}=0,287 ; \mathrm{p}=0,028<0,05\right)$. Hasil penelitian Holle (2009), berbeda dengan yang ditemukan oleh Piccolo, Takahasi, dan Naotakawatanabe (2005) yang meneliti 900 orang profesional baik medik, guru, tenaga farmasi dan pekerja perusahan di Jepang tentang hubungan kepuasan hidup dengan kebahagiaan; hasilnya bahwa kepuasan kerja tidak berhubungan positif dan signifikan dengan kebahagiaan. Instrumen yang dipergunakan dalam penelitian adalah Job Descriptive Index (JDI). Perbedaan hasil penelitian Holle (2009) dengan Piccolo, Takahasi, dan Naotakawatanabe (2005) mendorong peneliti mengadakan penelitian ulang untuk memastikan ada tidaknya hubungan signifikan antara kepuasan kerja guru dengan kebahagiaan.
Penelitian Bakker (2007) kepada 2038 orang guru dari 200 sekolah pada Departemen Pendidikan Helsinky, Findlandia dengan sampel guru SD sebesar 843 orang guru, guru SMP 497 orang guru, guru SMA 278 orang guru serta guru SMK 217 orang guru. Temuan penelitian bahwa ada hubungan negatif dan tidak signifikan antara stres guru dengan kebahagiaan guru $\left(r_{x y}=-0,105\right.$ dengan $\left.p=0,426>0,05\right)$. Sedangkan penelitian yang dilakukan oleh Anitawidanti (2010) yang melibatkan 260 orang karyawan pada PT. Transindo Surya Sarana Semarang menemukan hasil bahwa stres dan kebahagiaan memiliki hubungan negatif dan signifikan $\left(\mathrm{r}_{\mathrm{xy}}=-0,390\right.$ dengan $p=0,000<0,05)$.

Adanya hasil temuan yang berbeda dari Bakker (2007) dengan Anitawidanti (2010), mendorong peneliti melakukan penelitian lanjutan untuk membuktikan arah negatif dan ada tidaknya hubungan yang signifikan antara stres guru dengan kebahagiaan guru.

Hasil pra penelitian yang dilakukan oleh peneliti tentang hubungan kepuasan kerja guru dan stres guru dengan kebahagiaan guru pendidikan agama di Kota Ambon, dengan mengambil sampel sebanyak 30 orang guru pendidikan agama sekolah menengah yang sedang mengikuti pertemuan kelompok kerja guru (KKG) Pendidikan Agama, Kota Ambon dilaporkan pada Tabel 1.1 dan Tabel 1.2.

Tabel 1.1 Hubungan antara Kepuasan Kerja Guru dan Kebahagiaan

\begin{tabular}{cccc}
\hline & & Kepuasan kerja & Kebahagiaan \\
\hline Kepuasan & Pearson correlation & 1 & $0.390^{*}$ \\
& Sig. (2- tailed) & 30 & 0.033 \\
& $\mathrm{~N}$ & 30 \\
\hline
\end{tabular}

*Correlation is significant at the 0.05 level (2-tailed).

Tabel 1.1 menunjukkan bahwa $\mathrm{r}_{\mathrm{xy}}=$ 0,390 dengan $\mathrm{p}=0,033<0,05$. Jadi ada hubungan positif yang signifikan antara kepuasan kerja dan kebahagiaan guru dengan arah hubungan positif. 
Tabel 1.2 Hubungan antara Stres Guru dan Kebahagiaan

\begin{tabular}{llrr}
\hline & Stres guru & \multicolumn{2}{c}{ Kebahagiaan } \\
\hline Stres guru & Pearson correlation & 1 & -.040 \\
& Sig. (2- tailed) & & 0.834 \\
& $\mathrm{~N}$ & 30 & 30 \\
\hline
\end{tabular}

Tabel 1.2 menunjukkan bahwa arah hubungan negatif dan ada hubungan yang signifikan $\left(\mathrm{r}_{\mathrm{xy}}=-0.040\right.$, dan $\mathrm{P}=$ $0,834>0,05)$ antara stres guru dengan kebahagiaan.

Hasil pra penelitian menunjukkan bahwa dengan beban kerja yang semakin banyak, para guru agama mengalami tekanan langsung yang menyebabkan hilangnya kebahagiaan. Apalagi dampak konflik sosial di Maluku masih dirasakan dalam berbagai bidang kehidupan termasuk pendidikan hingga kini. Konflik sosial tersebut, juga berpengaruh dalam penurunan kualitas pendidikan di kota Ambon dan perkembangan komponenkomponen di bidang pendidikan terutama guru agama yang memiliki tanggungjawab untuk menyampaikan materi pelajaran tetapi juga memantau dan membentuk kecerdasan spiritual siswa.

Berdasarkan latarbelakang tersebut di atas, maka masalah penelitian ini dirumuskan sebagai berikut:

1. Adakah hubungan yang positif dan signifikan antara kepuasan kerja dengan kebahagiaan guru pendidikan agama Sekolah Menengah di Kota Ambon?

2. Adakah hubungan yang negatif dan signifikan antara stres guru dengan Kebahagiaan pada guru pendidikan agama Sekolah Menengah di Kota Ambon?

Sejalan dengan permasalahan penelitian, maka tujuan penelitian ini dirumuskan untuk mengetahui:
1. Signifikansi hubungan positif antara kepuasan kerja dengan Kebahagiaan pada guru pendidikan agama Sekolah Menengah di Kota Ambon.

2. Signifikansi hubungan negatif antara stres guru dengan kebahagiaan pada guru pendidikan agama Sekolah Menengah di Kota Ambon.

Dalam sejarah Psikologi, dikenal seorang pakar bernama Marthin P. Seligman yang dibesarkan dalam bidang psikologi klinis, yaitu psikologi yang melihat jiwa manusia sebagai mesin yang sering mengalami kerusakan. Psikologi klinis disebut sebagai psikologi bengkel yang hanya berkutat memperbaiki jiwa manusia. Psikologi sudah terlalu lama memusatkan perhatian terhadap cara mengatasi gangguan kejiwaan dan gejala-gejala psikopatologis. Sekitar 90\% kajian dalam psikologi didasari oleh model manusia yang sakit sebab orang-orang yang diteliti adalah mereka yang mengalami gangguan kejiwaan (Seligman, 2005).

\section{KAJIAN PUSTAKA}

\section{Pengertian Kebahagiaan}

Seligman tahun 1996 dalam pidato pada saat pemilihannya sebagai Presiden American Psychological Assosiatiation (APA), mengembangkan satu pendekatan yang ia namakan "Psikologi Positif". Sebagai pelopor utama psikologi positif, Seligman menggali pemikiran-pemikiran tentang kebahagiaan dari para filsuf dan 
tokoh-tokoh psikologi. Dalam filsafat ia menemukan pemikiran Aristoteles, dengan konsep eudemonia yang berarti "kehidupan yang lebih baik", well being, atau kebahagiaan. Istilah eudemonia juga dipakai oleh Thomas Jefferson dengan pengertian "pencapaian kebahagiaan". Istilah psikologi positif sendiri diambil dari Abraham Maslow dan Gordon W. Allport yang juga memimpikan psikologi yang mengkaji kualitas positif manusia (Al-Banjari, 2009).

Eudemonia menjadi salah satu konsep sentral dalam Psikologi Positif. Istilah ini menurut Seligman (2005) merujuk pada kebahagiaan yang dibedakan dari kenikmatan dalam pengertian Hedonisme. Kebahagiaan bukan kebahagiaan yang dicapai dengan kenikmatan ragawi, bukan ditandai oleh banyak senyum dan tawa terbahak-bahak. Eudemonia mengandung kenikmatan didalamnya, merupakan hasil dari kontemplasi dan percakapan yang bermakna. Di kalangan filsuf Yunani kuno, Socrates (Bertens, 1999) misalnya, menyatakan bahwa tujuan utama kehidupan manusia adalah kebahagiaan (eudamonia) yang hanya bisa dicapai dengan kekuatan atau kebajikan (arete). Plato menekankan bahwa kebahagiaan adalah kekuatan terpenting yang harus dikejar (Suseno, 1998), sementara Aristoteles lebih menekankan ajarannya pada sebuah prinsip dasar bahwa manusia hendaknya hidup dan bertindak sedemikian rupa sehingga dapat mencapai hidup yang baik, yang bermutu, dan yang berhasil.

Hidup yang penuh kebahagiaan (eudamonia) tidak merujuk pada perasaan temporer atau emosi kasar, juga bukan gairah hormonal atau orgasmik, melainkan kebahagiaan yang dihasilkan dari aktivitas memandang dan memahami hal yang baik
(Suseno, 1998). Csikszentmihalyi (1990) mengkonkretkan eudemonia sebagai keadaan yang diperoleh ketika mengalami percakapan yang lebih baik, saat berkontemplasi secara mendalam. Ketika orang mengalami eudemonia, waktu berhenti dan ia merasa sepenuhnya berada ditempat yang tepat. Pada saat itu, ia menjadi satu irama, satu penghayatan dengan dunia. Ibarat mendengarkan musik yang baik, si pendengar dan musiknya menyatu, mengalir bersama.

Hidup yang baik mengandung akarakar yang mengarahkan pada aliran itu, berisi pengetahuan pertama tentang kekuatan-kekuatan manusia, kemudian memperhalus kembali kehidupan kita untuk menghasilkan hal-hal yang baik. Dengan kebahagiaan kita menata kembali dan memperbaiki kerja, percintaan, pertemanan, waktu luang, dan kepedulian, mengatur kembali diri dan benda-benda untuk mendapatkan hasil terbaik. Eudemonia adalah kehidupan yang dapat dicapai melalui kekuatan karakter manusia. Aristoteles menyuratkan bahwa pemahaman terhadap diri sendiri merupakan syarat dari pencapaian kehidupan itu (Al-banjari, 2009).

Pesan psikolologi positif ialah mengingatkan bahwa bidang psikologi hanya setengah masak. Ada banyak kemajuan yang terjadi dalam studi tentang penyakit mental dan perbaikan kerusakan. Psikologi bukan hanya studi tentang penyakit, kelemahan, dan kerusakan. Psikologi juga adalah mempelajari tentang kebahagiaan, kekuatan dan kebajikan. Psikologi positif ingin memberikan pandangan tentang manusia dari sisi lain. Jika psikologi patologis memusatkan perhatian pada penderitaan, psikologi positif berkepentingan dengan kebahagiaan, karena 
selama ini psikologi hanya berkutat dengan sifat-sifat buruk manusia, psikologi positif ingin menampilkan sifat-sifat indah dari manusia.

Manusia bukan hanya makhluk rakus, homo avarus, yang mementingkan diri sendiri melainkan juga makhluk yang bisa hidup normal dengan mencintai dan dicintai. Dibalik awan kelabu kehidupan manusia betapapun gelapnya selalu tersisa garis-garis perak. Tugas psikologi positif adalah mempertegas garis-garis perak itu. Garis perak itu adalah kemungkinan untuk berubah menjadi lebih baik, untuk memunculkan kekuatan dan kebajikan (Seligman, 2005).

Menurut Seligman (2005) tidak ada jalan pintas untuk mempersingkat pencapaian kebahagiaan atau eudemonia. Kebahagiaan hanya dapat dicapai dengan memandang hidup sebagai hal yang bermakna dan berharga, mengenali diri, kemudian menemukan kekuatan-kekuatan dalam diri, lalu memanfaatkan kekuatankekuatan itu untuk kepentingan yang lebih besar.

'.the goals of the whole positive psychology enterprise, embracing both positif feelings (such as ecstacy and comfort) and positive activities that have no feelings component at all (such as absortion and engagement)" (Seligman 2002).

Dapat disimpulkan bahwa kebahagiaan menurut Seligman (2002) adalah kemampuan untuk belajar berpikir positif, memandang hidup dan orang lain sebagai hidup yang baik, memaknai dunia dan seisinya sebagai kebaikan yang dianu- gerahkan, kemudian bersyukur atas semua anugerah itu.

\section{Faktor-Faktor Yang Mempengaruhi Kebahagiaan}

\section{Faktor Internal}

Tiga faktor internal yang berkontribusi terhadap kebahagiaan, yaitu kepuasan terhadap masa lalu, optimisme terhadap masa depan, dan kebahagiaan pada masa yang sekarang.

\section{Faktor Eksternal}

Seligman (2005) menyampaikan delapan faktor eksternal yang mempengaruhi kebahagiaan seseorang, namun tidak semuanya memiliki pengaruh yang besar. Berikut ini adalah penjabaran dari faktorfaktor eksternal yang berkontribusi pada kebahagian seseorang: Uang, Pernikahan, Kehidupan Sosial, Emosi Negatif, Usia, Kesehatan, Pendidikan, Iklim, Ras dan Jenis Kelamin, Agama, Kebajikan dan Kebahagiaan Manusia.

Seligman dan Peterson (2005) membaca tulisan-tulisan fundamental dari semua agama utama dan tradisi filsafat, tujuannya agar dapat menyusun katalog tentang hal-hal yang dianggap kebajikan oleh setiap agama dan tradisi filsafat itu. Setelah membaca karya Aristoteles, Plato, Aquinas, dan St. Agustinus; Perjanjian lama dan Talmud, Konfusius, Buddha, Lao-tse, Bushido (kode etik samurai), Al Quran; tulisan Benjamin Franklin dan Upanishads, semuanya sekitar 20 katalog tentang kebajikan. Temuan mengejutkan adalah, hampir semua tradisi ini yang berjalan selama tiga ribu tahun dan tersebar diseluruh muka bumi mendorong 6 buah kebajikan manusia, yaitu: (1) Kebijaksanaan dan pengetahuan; (2) Keberanian; (3) Kemanusiaan dan Cinta; 
(4) Keadilan; (5) kesederhanaan; serta (6) Spiritualitas dan transendensi.

\section{Pengukuran Kebahagiaan}

Ada 3 orang ahli yang mengembangkan alat untuk mengukur kebahagiaan yaitu: (1) Fordyce Happiness Measure (FHM, 1988). Oleh W. Fordyce yang menekankan bahwa kebahagian adalah kekuatan mengatur emosi manusia atau kebahagiaan sementara; (2) General Happiness Scale (GHS) yang dikembangkan oleh Lyubomirsky dan Lepper (1999) yang mengukur kebahagiaan secara umum; (3)Authentic Happiness Inventory (AHI) yang dikembangkan oleh Seligman dan Peterson (2005), yang menitik beratkan pada 24 kekuatan kebajikan manusia sebagai kekuatan untuk mencapai kebahagiaan. Dalam Penelitian ini digunakan authentic happiness inventory (AHI).

\section{Pengertian Kepuasan Kerja Guru}

Kerja merupakan sesuatu yang di butuhkan oleh manusia. Manusia bekerja karena ada sesuatu yang hendak dicapainya dan manusia berharap bahwa aktivitas kerja yang dilakukannya akan membawa kepada suatu keadaan yang lebih memuaskan dari pada keadaan sebelumnya. Manusia memiliki kebutuhan yang harus dipenuhi dalam kehidupannya dan untuk memenuhi kebutuhan tersebut salah satunya adalah dengan bekerja.

Guru menjadi pelaku yang menunjang tercapainya tujuan pendidikan, mempunyai pikiran, perasaan dan keinginan yang dapat mempengaruhi sikap-sikap terhadap pekerjaannya. Sikap guru akan menentukan kinerja, dedikasi, dan kecintaan terhadap pekerjaan yang dibebankan di pundaknya. Sikap positif harus dikembangkan, sedang yang negatif harus diminimalkan. Sikap guru seperti tidak puas bekerja, stres dan frustrasi dapat ditimbulkan karena adanya pekerjaan, peralatan, lingkungan, dan iklim organisasi. Kepuasan kerja guru merupakan gejala kompleks yang memiliki berbagai faktor yang berhubungan yaitu personal, sosial, budaya dan ekonomi. Kepuasan kerja guru merupakan hasil dari berbagai sikap seseorang terhadap pekerjaannya dan faktor-faktor yang berhubungan dengan pekerjaannya dan terhadap kerja pada umumnya.

Herszberg (dalam Dahlan, 2007) mengembangkan teori kepuasan kerja yang disebut teori dua faktor, dengan prinsip bahwa kepuasan dan ketidakpuasan itu merupakan dua hal yang berbeda, artinya kepuasan dan ketidak puasan terhadap pekerjaan itu merupakan satu kontinum. Berdasarkan penelitiannya Herzberg membagi situasi yang mempengaruhi sikap seseorang terhadap pekerjaannya menjadi dua kelompok yaitu puas (motivator) dan tidak puas (pemeliharaan). Puas adalah faktor-faktor atau situasi-situasi yang dibuktikannya sebagai sumber kepuasan kerja yang terdiri dari prestasi/hasil yang dicapai, penghargaan, pekerjaan itu sendiri, tanggungjawab dan kemajuan. Tidak puas adalah faktor-faktor yang menjadi sumber ketidak puasan yang terdiri dari peraturanperaturan, administrasi, pengawasan, gaji, hubungan antar pribadi, kondisi kerja dan status. Menurut teori ini perbaikan gaji dan kondisi kerja tidak akan menimbulkan kepuasan tetapi hanya mengurangi ketidakpuasan.

Teori Herzberg dikenal orang sebagai two faktor theory atau motivator hygiene theory. Kebutuhan tingkat atas 
pada teori Herzberg yang diturunkan dari Maslow adalah harga diri dan aktualisasi diri yang disebut sebagai motivator, sedangkan kebutuhan yang lain digolongkan menjadi kebutuhan bawah yang disebut sebagai hygiene faktor.

Menurut Lester (dalam Hughes, 2006) kepuasan kerja guru didefenisikan sebagai lingkup dari persepsi pegawai dan nilai dari karakteristik lingkungan pekerjaan seperti kompensasi, otonomi, rekan kerja, dan produktivitas. Kepuasan kerja guru sebagai sejauhmana penerimaan dan nilainilai yang dirasakan oleh guru terhadap banyaknya faktor seperti evaluasi, hubungan rekan kerja, tanggungjawab, dan penghargaan.

\section{Pengukuran Kepuasan Kerja Guru}

Ada alat ukur yang telah dikembangkan untuk mengukur kepuasan kerja yaitu: (1) Job descriptif index (JDI); (2) Minesotta Satisfaction Questionnaire (MSQ), namun menurut Hill (dalam Hughes, 2006) walaupun terdapat alat-alat untuk mengukur kepuasan kerja di dalam bisnis dan industri, instrumen-instrumen kepuasan kerja seperti tersebut tidak cocok di terapkan di dalam lingkungan kerja atau institusi pendidikan; dan (3) Teachers Job Satisfaction Quetionnaire (TJSQ) yang dikembangkan oleh Lester (1984) secara khusus untuk digunakan dalam pendidikan dan dipilih untuk digunakan dalam penelitian ini.

\section{Pengertian Stres Guru}

Loekmono (2005) menyatakan bahwa profesi guru adalah profesi pelayanan yang mengandung potensi mengalami stres kuat dan pemicu munculnya stres dalam pekerjaannya. Dalam penelitian Loekmono (2005) kepada guru pendidikan dasar dan menengah di Waingapu Kabupaten Sumba Timur ditemukan bahwa pada umumnya guru berada pada tingkat 'tidak mengalami stres' sampai "stres sedang' sebesar $84,4 \%$. sedangkan 12,6 $\%$ telah mengalami tingkat 'stres kuat' dan 'sangat kuat'. Faktor yang menjadi sumber stres (stresor) adalah:(1) sarana mengajar tidak memadai, (2) kurangnya fasilitas yang dibutuhkan dalam mengajar; dan (3) berusaha mempertahankan nilai atau standar sekolah.

Kyriacou (dalam Loekmono, 2005) mendefinisikan stres guru sebagai pengalaman seorang guru yang tidak menyenangkan, seperti ketegangan, frustrasi, cemas, marah, dan depresi, sebagai akibat dari aspek pekerjaan sebagai seorang guru. Ketegangan atau tekanan itu berasal dari berbagai sumber stres (stresor) dan dipersepsikan sebagai ancaman terhadap kebahagiaan psikologis dan fisiologis individu yang bersangkutan.

Kyriacou (dalam Loekmono, 2005) telah melakukan penelitian dengan mengirim angket kepada kepala sekolah sebanyak 242 orang guru. Guru menjawab tanpa menulis namanya. Hasil kajian menunjukkan bahwa sekitar $20 \%$ responden menyatakan kurang mengalami stres pada tingkat 'sangat kuat' dalam menjalankan tugas mengajarnya sehari-hari. Hanya terdapat hubungan yang rendah antara tingkat stres laporan diri (self report) dengan ciri-ciri demografi guru. Menurut Kyriacou (dalam Loekmono, 2005) guru yang mengalami emosi negatif selama menjalankan tugas seperti kekecewaan, kema- 
rahan, ketegangan, keresahan berpotensi sangat kuat untuk mengalami stres.

Penelitian Kyriacou (dalam Loekmono, 2005) sejalan dengan hasil penelitian yang dilakukan oleh Chao (1995) tentang hubungan antara stres guru dan kepuasan kerja dengan dukungan sosial pada 50 orang guru sekolah dasar dan 50 orang guru sekolah menegah di Hongkong. Chao (1995) menemukan bahwa 61\% responden mengalami stres pada tingkat "sangat kuat. Demikian pula hasil penelitian The professional Teacher union of Hongkong (1995) menemukan bahwa dari 1.100 kuesioner yang dibagikan secara random sampling pada guru-guru di Hongkong, hasil penelitian yang diperoleh adalah $66 \%$ responden mengalami stres pada tingkat "sangat kuat". Hal ini disebabkan oleh beberapa hal yaitu: sikap siswa yang tidak sesuai aturan, kelas yang terlalu besar, terlalu banyak aturan serta tingginya beban kerja.

\section{Pengukuran Stres Guru}

Ada alat tersedia untuk mengukur tingkat stres antara lain (1) Scale Stres Questionnaire (SSQ); (2) Administrative stres Indeks (ASI) yang dikembangkan oleh Gmelh dan Swent (1982); (3) Kuesioner tingkat stres guru merupakan instrumen berdasarkan Kyriacou dan dimodifikasi oleh Loekmono (1999) dan telah dipergunakan juga dalam penelitian Alunpha (2005) dan di pilih untuk digunakan dalam penelitian ini, terdiri dari 42 item dalam bentuk skala likert yang dikelompokkan dalam dua bagian, bagian pertama yakni 42 item yang merupakan sumber-sumber stres.

Dari 42 item tersebut dikelompokkan menjadi empat sub bagian, yaitu:

(1) Perilaku peserta didik terdiri dari 11 item; (2) suasana pekerjaan terdiri dari 10 item, (3) tekanan waktu terdiri dari 10 item; dan (4) etos kerja terdiri dari 11 item dengan empat skala kemungkinan jawaban diberi skor 1, 2, 3 dan 4 .

\section{METODE PENELITIAN}

\section{Jenis Dan Lokasi Penelitian}

Jenis penelitian ini adalah penelitian korelasional yaitu penelitian untuk mengetahui ada tidaknya hubungan antara dua atau beberapa variabel (Arikunto, 1998). Dengan teknik korelasi, peneliti mencari hubungan antara variabel bebas, yaitu kepuasan kerja guru $\left(\mathrm{X}_{1}\right)$, Stres Guru $\left(\mathrm{X}_{2}\right)$ dengan variabel terikat kebahagiaan (Y) bagi guru pendidikan agama sekolah menengah di Kota Ambon.

Lokasi penelitian adalah pada sekolah menengah di 5 kecamatan yaitu Nusaniwe, Sirimau, Teluk Ambon, Baguala, dan Leitimur selatan yang berada di kota Ambon, dengan satuan pengamatan dan satuan analisisnya adalah guru-guru pendidikan agama sekolah menengah (SMA dan SMK).

\section{Populasi Dan Sampel}

Populasi dalam penelitian ini adalah semua guru pendidikan agama Sekolah menengah di kota Ambon, berjumlah 117 orang guru (data Diskor Kota Ambon, 2011). Oleh karena jumlah populasi yang relatif masih terjangkau maka peneliti menggunakan teknik Saturasi, artinya setiap anggota populasi menjadi sampel (Sugiyono, 2011).

\section{Instrumen Penelitian}

Untuk mengukur variabel kebahagiaan digunakan Authentic Happiness Inventory (AHI) yang dikembangkan 
oleh Seligman dan Peterson, terdiri dari 24 pertanyaan dalam bentuk pilihan ganda dan berisi 5 pilihan jawaban dari A, B, C, D, dan E. pemberian skor Authentic happiness Inventory (AHI) dilakukan dengan cara memberi skor 1,2,3,4 dan 5; instrumen yang digunakan untuk mengukur variabel kepuasan kerja guru adalah menggunakan Teacher Job Satisfaction Questionnaire (TJSQ) dikembangkan oleh Lester (1984) yang berisi 66 item pernyataan dalam bentuk Skala Likert dengan empat kemungkinan jawaban, yakni: "sangat tidak setuju (STS)", "Tidak setuju (TS)", dan "sangat setuju (SS)". Untuk mengukur variabel stres guru digunakan Angket Stres Guru yang dikembangkan oleh Kyriacou yang diadaptasi oleh Lobby Loekmono berisi 42 pernyataan dalam bentuk Skala Likert yang berkaitan dengan sumber stres guru dengan empat kemungkinan jawaban, yakni:"sangat tidak setuju (STS)", "Tidak setuju (TS)", dan "sangat setuju (SS)". Empat skala kemungkinan jawaban diberi skor 1, 2, 3 dan 4 .

\section{Deskripsi Subjek Penelitian}

Subjek penelitian ini sebanyak 117 orang guru agama sekolah menengah di kota Ambon dideskripsikan pada Tabel 1 sampai Tabel 5.

Deskripsi subjek penelitian berdasarkan jenis kelamin seperti pada Tabel 1 berikut:

Tabel 1 Deskripsi Subjek Penelitian berdasarkan Jenis Kelamin

\begin{tabular}{ccc}
\hline Jenis kelamin & f & Persentase (\%) \\
\hline Laki-laki & 56 & 47.86 \\
Perempuan & 61 & 52,14 \\
\hline Jumlah & 117 & 100 \\
\hline
\end{tabular}

Sumber: Data Responden, 2011.
Tabel 1 menggambarkan bahwa mayoritas responden $52,14 \%$ atau 61 orang guru pendidikan agama di kota Ambon adalah guru perempuan.

Deskripsi subjek penelitian berdasarkan Agama, dapat dilihat pada Tabel 2:

Tabel 2 Deskripsi Subjek Penelitian berdasarkan

\begin{tabular}{ccc}
\multicolumn{3}{c}{ Agama } \\
\hline Agama & $\mathbf{f}$ & Persentase (\%) \\
\hline Islam & 49 & 41,88 \\
Katolik & 9 & 7.69 \\
Kristen Protestan & 59 & 50,42 \\
Hindu & 0 & 0 \\
Budha & 0 & 0 \\
\hline Jumlah & 117 & 100 \\
\hline
\end{tabular}

Sumber: data Responden 2011.

Tabel 2 menggambarkan bahwa mayoritas responden guru pendidikan agama Kristen Protestan 50,42\% (59 orang guru) dari 117 responden.

Deskripsi subjek penelitian berdasarkan jenjang pendidikan, dapat dilihat pada Tabel 3, berikut:

Tabel 3 Deskripsi Subjek Penelitian berdasarkan Jenjang Pendidikan

\begin{tabular}{ccc}
\hline Pendidikan & f & Persentase (\%) \\
\hline Magister (S2) & 10 & 8,55 \\
Sarjana (S1) & 104 & 88,89 \\
Diploma & 3 & 2,56 \\
PGA & 0 & 0 \\
\hline Jumlah & 117 & 100
\end{tabular}

Sumber: data Responden 2011.

Tabel 3 menunjukkan bahwa sebagian besar guru pendidikan agama sekolah menengah di kota Ambon adalah guru yang memiliki jenjang pendidikan Sarjana (S1) sebanyak 88,89\%.

Deskripsi subjek penelitian berdasarkan Golongan dapat dilihat pada Tabel 4:

Tabel 4 Deskripsi Subjek Penelitian berdasarkan Pangkat/Golongan

\begin{tabular}{ccc}
\hline Golongan & $\mathrm{f}$ & Persentase (\%) \\
\hline Golongan IV & 42 & 35,89 \\
Golongan III & 61 & 52,14 \\
Golongan II & 14 & 11,97 \\
Golongan I & 0 & 0 \\
\hline Jumlah & 117 & 100 \\
\hline
\end{tabular}

Sumber: data Responden 2011. 
Tabel 4 menunjukkan bahwa sebagian besar (61 orang) guru agama sekolah menengah di kota Ambon $(52,14 \%)$ berada pada golongan III.

Deskripsi subjek penelitian berdasarkan masa kerja, dapat dilihat pada Tabel 5 berikut:

Tabel 5 Deskripsi Subjek Penelitian berdasarkan Masa Kerja

\begin{tabular}{ccc}
\hline Masa Kerja (tahun) & f & Persentase $(\%)$ \\
\hline $26-30$ & 7 & 5,98 \\
$21-25$ & 21 & 17,94 \\
$16-20$ & 26 & 22,22 \\
$11-15$ & 8 & 6,84 \\
$6-10$ & 32 & 27,35 \\
$1-5$ & 23 & 19,67 \\
\hline Jumlah & 117 & 100 \\
\hline
\end{tabular}

Sumber: data Responden 2011.

Tabel 5 menunjukkan bahwa sebagian besar guru pendidikan agama sekolah menengah di kota Ambon sebagian besar telah bekerja selama 6-10 tahun $(27,35 \%)$.

\section{HASIL PENELITIAN DAN PEMBA- HASAN}

\section{Analisis Deskriptif}

\section{Kebahagiaan (Y)}

Deskripsi kategori kebahagiaan guru agama sekolah menengah di kota Ambon, dapat dilihat pada Tabel 6 berikut ini:

Tabel 6 Tabel Deskripsi Kategori Kebahagiaan

\begin{tabular}{cccc}
\multicolumn{5}{c}{ Guru Agama } \\
\hline Kategori & Skor & $\mathbf{f}$ & $\begin{array}{c}\text { Presen- } \\
\text { tase }(\%)\end{array}$ \\
\hline Sangat bahagia & $100-120$ & 0 & 0 \\
Bahagia & $81-99$ & 28 & 23,94 \\
Sedang & $62-80$ & 49 & 41,88 \\
Tidak bahagia & $43-61$ & 40 & 34,18 \\
Sangat tidak & $24-42$ & 0 & 0 \\
bahagia & & & \\
\hline Jumlah & & 117 & 100
\end{tabular}

Sumber: data Primer diolah, 2011
Tabel 6 menunjukkan sebagian besar guru memiliki kebahagiaan pada kategori "Sedang" (41,88\%).

\section{Kepuasan Kerja Guru $\left(\mathbf{X}_{1}\right)$}

Deskripsi kepuasan kerja guru agama sekolah menengah di kota Ambon, dapat dilihat pada Tabel 7 berikut ini:

Tabel 7 Tabel Deskripsi Kategori Kepuasan Kerja Guru Agama

\begin{tabular}{cccc}
\hline Kategori & Skor & f & $\begin{array}{c}\text { Presen- } \\
\text { tase (\%) }\end{array}$ \\
\hline Sangat puas & $229-269$ & 0 & 0 \\
Puas & $188-228$ & 10 & 8,55 \\
Sedang & $147-187$ & 52 & 44,44 \\
Tidak puas & $106-146$ & 29 & 24,79 \\
$\begin{array}{c}\text { Sangat Tidak } \\
\text { puas }\end{array}$ & $66-105$ & 26 & 22,22 \\
\hline Jumlah & & 117 & 100 \\
\hline
\end{tabular}

Sumber: data Primer diolah, 2011

Tabel 7 menunjukkan bahwa sebagian besar kepuasan kerja guru berada pada kategori "Sedang” (44,44\%).

\section{Stres Guru}

Deskripsi kategori stres guru pendidikan agama sekolah menengah di kota Ambon, dapat dilihat pada Tabel 8 berikut ini:

Tabel 8 Tabel Deskripsi Kategori Stres Guru

\begin{tabular}{cccc}
\hline Kategori & skor & $\mathbf{f}$ & $\begin{array}{c}\text { Presen- } \\
\text { tase (\%) }\end{array}$ \\
\hline Sangat tinggi & $146-171$ & 10 & 8,55 \\
Tinggi & $120-145$ & 29 & 24,78 \\
Sedang & $94-119$ & 32 & 27,35 \\
Rendah & $68-93$ & 38 & 32,47 \\
Sangat rendah & $42-67$ & 8 & 6,85 \\
\hline \multicolumn{4}{c}{117} \\
\hline Sumber: data Primer diolah, 2011 \\
Tabel 8 menunjukkan bahwa \\
sebagian besar guru pendidikan agama \\
sekolah menengah di kota Ambon, \\
memiliki tingkat stres pada kategori \\
"Rendah" (32,47\%).
\end{tabular}




\section{Analisis Korelasi}

Sugiyono (2011) menyatakan bahwa penggunaan Pearson product moment yang merupakan statistik parametrik, jika data setiap variabel penelitian yang akan dianalisis membentuk distribusi normal.

Uji normalitas kebahagiaan (Y), kepuasan kerja guru $\left(\mathrm{X}_{1}\right)$, dan stres guru $\left(\mathrm{X}_{2}\right)$ dapat dilihat pada diagram batang serta Kolmogrov-smirnov berikut ini:

One-Sample Kolmogorov-Smirnov Test

\begin{tabular}{|ll|r|}
\hline & & \multicolumn{1}{|c|}{$\mathrm{Y}$} \\
\hline $\mathrm{N}$ & 117 \\
Normal Parameters $^{\mathrm{a}}{ }^{\mathrm{a}}$ & Mean & 46.77 \\
& Std. Deviation & 13.442 \\
Extreme Differences & Absolute & .113 \\
& Positive & .113 \\
& Negative & -.086 \\
Kolmogorov-Smirnov Z & 1.225 \\
Asymp. Sig. (2-tailed) & .099 \\
\hline \multicolumn{2}{|l|}{ a. Test distribution is Normal. } & \\
\hline
\end{tabular}

Koefisien Kolmogorov-smirnov Z $=1,225$ dengan taraf signifikansi 0,099. Hal ini menunjukkan bahwa distribusi sebaran hasil pengukuran untuk variabel kebahagiaan adalah normal, karena taraf signifikansi lebih besar dari $0,05(0,099$ $>0,05$ ).

\section{one-Sample Kolmogorov-Smirnov Test}

\begin{tabular}{|ll|r|}
\hline & & \multicolumn{1}{|c|}{$\mathrm{X}_{1}$} \\
\hline $\mathrm{N}$ & & 117 \\
Normal Parameters $^{\mathrm{a}}$ & Mean & 125.59 \\
& Std. Deviation & 26.967 \\
& & .065 \\
Most Extreme Differences & Absolute & .051 \\
& Positive & -.065 \\
& Negative & .701 \\
Kolmogorov-Smirnov Z & & .710 \\
Asymp. Sig. (2-tailed) & & \\
\hline
\end{tabular}

Koefisien Kolmogorov-smirnov untuk $\left(\mathrm{X}_{1}\right)$ adalah 0,701 dengan taraf signifikansi 0,710 . Hal ini menunjukkan bahwa distribusi sebaran hasil pengukuran untuk variabel kepuasan kerja guru $\left(\mathrm{X}_{1}\right)$ adalah normal, karena taraf signifikansi $=$ $0,710>0,05$.

One-Sample Kolmogorov-Smirnov Test

\begin{tabular}{|c|c|c|}
\hline & $\mathrm{X}_{2}$ \\
\hline \multicolumn{2}{|l|}{$\mathrm{N}$} & 117 \\
\hline \multirow[t]{2}{*}{ Normal Parameters ${ }^{\mathrm{a}}$} & Mean & 107.71 \\
\hline & Std. Deviation & 25.281 \\
\hline \multirow{3}{*}{$\begin{array}{l}\text { Most Extreme } \\
\text { Differences }\end{array}$} & Absolute & .104 \\
\hline & Positive & .104 \\
\hline & Negative & -.058 \\
\hline \multicolumn{2}{|c|}{ Kolmogorov-Smirnov Z } & 1.128 \\
\hline \multicolumn{2}{|l|}{ Asymp. Sig. (2-tailed) } & .157 \\
\hline a. Test distribution is & rmal. & \\
\hline
\end{tabular}
1,128 dengan taraf signifikansi 0,157 . Hal ini menunjukkan bahwa distribusi sebaran hasil pengukuran untuk variabel stres guru $\left(\mathrm{X}_{2}\right)$ adalah normal, karena taraf signifikansi $=0,157>0,05$.

\section{Hubungan Kepuasan kerja $\left(\mathrm{X}_{1}\right)$ dengan Kebahagiaan (Y)}

Tabel 9 Hasil Uji Korelasi antara Kepuasan Kerja Guru $\left(\mathrm{X}_{1}\right)$ dengan Kebahagiaan $(\mathrm{Y})$

\begin{tabular}{llrr}
\hline & & $\begin{array}{l}\text { Kepuas- } \\
\text { an kerja }\end{array}$ & $\begin{array}{l}\text { Keba- } \\
\text { hagiaan }\end{array}$ \\
\hline Kepuasan & $\begin{array}{l}\text { Pearson } \\
\text { correlation }\end{array}$ & 1 & $0.202^{*}$ \\
& $\begin{array}{l}\text { Sig. (1- tailed) } \\
\text { N }\end{array}$ & & 0.014 \\
& & 117 & 117 \\
\hline${ }^{*}$ Correlation is significant at the 0.05 level (1-tailed).
\end{tabular}

Berdasarkan data pada Tabel 9 koefisien korelasi kepuasan kerja guru dengan kebahagiaan berarah positif $=$ 0,202 dengan $p=0,014<0,05$. Jadi ada hubungan positif signifikan antara kepuasan kerja dengan kebahagiaan pada taraf signifikansi $5 \%$. 
Hubungan Stres guru $\left(\mathrm{X}_{2}\right)$ dengan Kebahagiaan (Y)

Tabel 10 Hasil Uji Korelasi antara Stres Guru $\left(\mathrm{X}_{2}\right)$ dengan Kebahagiaan(Y)

\begin{tabular}{llrr}
\hline & & $\begin{array}{r}\text { Kepuas- } \\
\text { an kerja }\end{array}$ & $\begin{array}{c}\text { Keba- } \\
\text { hagiaan }\end{array}$ \\
\hline Kepuasan & $\begin{array}{l}\text { Pearson } \\
\text { correlation } \\
\text { Sig. (1-tailed) }\end{array}$ & 117 & -0.137 \\
N & & 0.070 \\
117
\end{tabular}

Berdasarkan data pada Tabel 10 nampak koefisien korelasi antara stres guru dengan kebahagiaan guru berarah negatif sebesar $-0,137$, dengan $p=0,070$ $>0,05$. Jadi tidak ada hubungan yang signifikan antara stres guru dengan kebahagiaan dan arah hubungan negatif.

Karena tidak ada korelasi yang signifikan, maka dilakukan analisis lebih lanjut untuk setiap sub konsep pada stres guru dengan kebahagiaan. Dapat dilihat dalam Tabel 11 - Tabel 14 berikut ini:

Tabel 11 Hasil Uji Korelasi Sub Konsep Perilaku Peserta Didik $\left(\mathrm{X}_{2.1}\right)$ dengan Kebahagiaan (Y)

\begin{tabular}{llrr}
\hline & & $\begin{array}{r}\text { Kepuas- } \\
\text { an kerja }\end{array}$ & $\begin{array}{l}\text { Keba- } \\
\text { hagiaan }\end{array}$ \\
\hline Perilaku & $\begin{array}{l}\text { Pearson } \\
\text { peserta didik correlation }\end{array}$ & 1 & -0.061 \\
& & \\
Sig. (1-tailed) & 117 & 0.257 \\
$\mathrm{~N}$ & & 117 \\
\hline
\end{tabular}

Pada Tabel 11 menunjukkan koefisien korelasi antara sub konsep perilaku peserta didik dengan kebahagiaan $=-0,061$, dengan $p=0,257$. Berpedoman pada taraf signifikansi $5 \%$ didapatkan $p=0,257$ > 0,05 , maka korelasi antara sub konsep perilaku peserta didik dengan kebahagiaan dinyatakan tidak signifikan. Artinya, jika skor sub konsep perilaku peserta didik naik maka skor kebahagiaan tidak dapat ditentukan.
Tabel 12 Hasil Uji Korelasi Sub Konsep Suasana Kerja/Kekerjaan $\left(\mathrm{X}_{2.2}\right)$ dengan Kebahagiaan (Y)

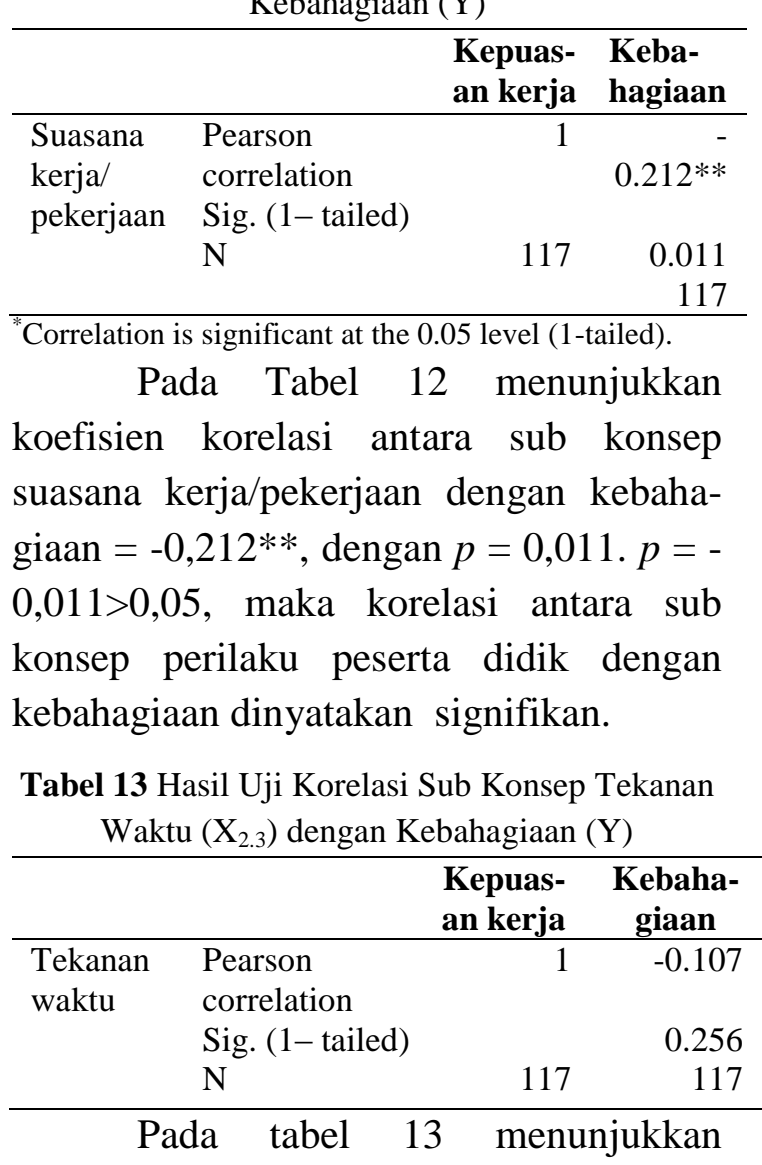

koefisien korelasi antara sub konsep perilaku peserta didik dengan kebahagiaan $=-0,107$, dengan $p=0,256 .>0,05$, maka korelasi antara sub konsep tekanan waktu dengan kebahagiaan dinyatakan tidak signifikan.

Tabel 14 Hasil Uji Korelasi Sub Konsep Etos Kerja $\left(\mathrm{X}_{2.4}\right)$ dengan Kebahagiaan $(\mathrm{Y})$

\begin{tabular}{|c|c|c|c|}
\hline & & $\begin{array}{l}\text { Kepuas- } \\
\text { an kerja }\end{array}$ & $\begin{array}{c}\text { Keba- } \\
\text { hagiaan }\end{array}$ \\
\hline \multirow{4}{*}{$\begin{array}{l}\text { Etos } \\
\text { kerja }\end{array}$} & Pearson & 1 & -0.138 \\
\hline & correlation & & \\
\hline & Sig. $(1-$ tailed $)$ & & 0.069 \\
\hline & $\mathrm{N}$ & 117 & 117 \\
\hline
\end{tabular}

koefisien korelasi antara sub konsep perilaku peserta didik dengan kebahagiaan $=-0,138$, dengan $p=0,069 .>0,05$, maka korelasi antara sub konsep etos kerja dengan kebahagiaan dinyatakan tidak signifikan. 
Karena sub konsep suasana kerja/ pekerjaan $\left(\mathrm{X}_{2.2}\right)$ menujukkan ada hubungan negatif dan tidak signifikan, maka dilakukan analisis lanjutan terhadap indikator-indikator empirik dalam sub konsep tersebut. Deskripsinya ditunjukkan pada Tabel 15 sampai Tabel 24.

Tabel 15 Deskripsi Kategori Sub Konsep Suasana Kerja $\left(\mathrm{X}_{2.2}\right)$, Indikator Empirik Kurangnya Hukuman yang Memadai

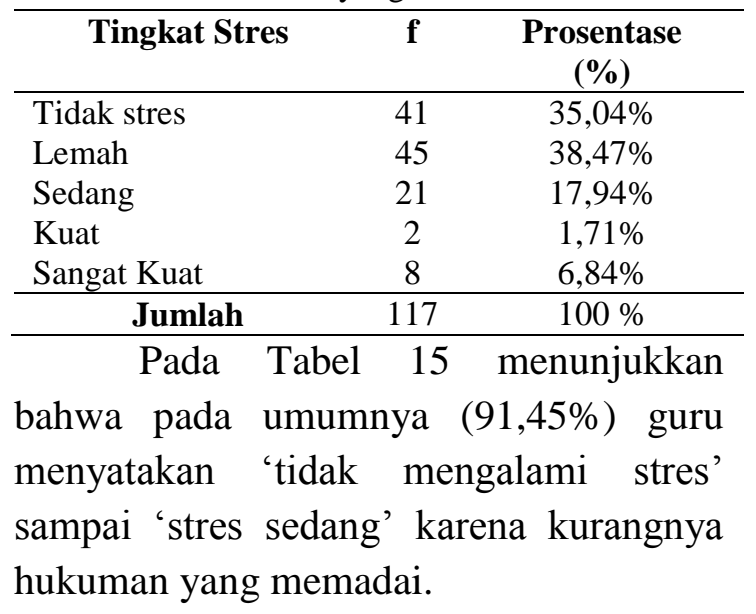

Tabel 16 Deskripsi Kategori Sub Konsep Suasana Kerja $\left(\mathrm{X}_{2.2}\right)$ Indikator Empirik Kurangnya Peluang untuk Naik Pangkat atau Golongan

\begin{tabular}{lcc}
\hline \multicolumn{1}{c}{ Tingkat Stres } & f & Prosentase (\%) \\
\hline Tidak stres & 6 & $5,13 \%$ \\
Lemah & 9 & $7,69 \%$ \\
Sedang & 11 & $9,40 \%$ \\
Kuat & 42 & $35,90 \%$ \\
Sangat Kuat & 49 & $41,88 \%$ \\
\hline \multicolumn{1}{c}{ Jumlah } & 117 & $100 \%$ \\
\hline \multicolumn{1}{c}{ Pada Tabel } & 16 & menunjukkan
\end{tabular}

bahwa pada umumnya $(87,18 \%)$ guru menyatakan 'stres sedang' sampai "stres sangat kuat" karena kurangnya peluang untuk naik pangkat atau golongan.

Tabel 17 Deskripsi Kategori Sub Konsep Suasana Kerja $\left(\mathrm{X}_{2.2}\right)$ Indikator Empirik Gaji Tidak Memadai

\begin{tabular}{lcc}
\hline \multicolumn{1}{c}{ Tingkat Stres } & f & Prosentase (\%) \\
\hline Tidak stres & 3 & $2,56 \%$ \\
Lemah & 40 & $34,19 \%$ \\
Sedang & 51 & $43,59 \%$ \\
Kuat & 17 & $14,53 \%$ \\
Sangat Kuat & 6 & $5,13 \%$ \\
\hline \multicolumn{1}{c}{ Jumlah } & 117 & $100 \%$ \\
\hline
\end{tabular}

Pada Tabel 17 menunjukkan bahwa pada umumnya $(80,34 \%)$ guru menyatakan 'tidak mengalami stres' sampai 'stres sedang' karena gaji tidak memadai.

Tabel 18 Deskripsi Kategori Sub Konsep Suasana Kerja $\left(\mathrm{X}_{2.2}\right)$ Indikator Empirik Sarana Mengajar Tidak Memadai

\begin{tabular}{|c|c|c|}
\hline Tingkat Stres & f & Prosentase $(\%)$ \\
\hline Tidak stres & 7 & $5,98 \%$ \\
\hline Lemah & 20 & $17,09 \%$ \\
\hline Sedang & 41 & $35,04 \%$ \\
\hline Kuat & 33 & $28,21 \%$ \\
\hline Sangat Kuat & 16 & $13,68 \%$ \\
\hline Jumlah & 117 & $100 \%$ \\
\hline Pada & 18 & menunjukkan \\
\hline
\end{tabular}

bahwa pada umumnya $(76,93 \%)$ guru menyatakan "stres sedang" sampai 'stres sangat kuat' karena sarana mengajar tidak memadai.

Tabel 19 Deskripsi Kategori Sub Konsep Suasana Kerja $\left(\mathrm{X}_{2.2}\right)$ Indikator Empirik Guru Kurang Dilibatkan dalam Membuat Keputusan

\begin{tabular}{lcc}
\hline \multicolumn{1}{c}{ Tingkat Stres } & f & Prosentase (\%) \\
\hline Tidak stres & 27 & $23,08 \%$ \\
Lemah & 19 & $16,24 \%$ \\
Sedang & 56 & $47,86 \%$ \\
Kuat & 7 & $5,98 \%$ \\
Sangat Kuat & 8 & $6,84 \%$ \\
\hline \multicolumn{1}{r}{ Jumlah } & 117 & $100 \%$ \\
\hline \multicolumn{1}{r}{ Pada } & Tabel 19 & menunjukkan
\end{tabular}
bahwa pada umumnya $(87,18 \%)$ guru menyatakan 'tidak mengalami stres' sampai "stres sedang" karena guru kurang dilibatkan dalam membuat keputusan.

Tabel 20 Deskripsi Kategori Sub Konsep Suasana Kerja $\left(\mathrm{X}_{2.2}\right)$ Indikator Empirik Kelas Besar atau Siswa Banyak

\begin{tabular}{lcc}
\hline \multicolumn{1}{c}{ Tingkat Stres } & f & Prosentase (\%) \\
\hline Tidak stres & 25 & $21,36 \%$ \\
Lemah & 32 & $27,35 \%$ \\
Sedang & 40 & $34,19 \%$ \\
Kuat & 12 & $10,26 \%$ \\
Sangat Kuat & 8 & $6,84 \%$ \\
\hline \multicolumn{1}{c}{ Jumlah } & 117 & $100 \%$ \\
\hline \multicolumn{1}{c}{ Pada } & Tabel 20 & menunjukkan \\
bahwa pada & umumnya & $(82,9 \%)$ guru
\end{tabular}

bahwa pada umumnya $(82,9 \%)$ guru 
menyatakan'tidak mengalami stres' sampai 'stres sedang' karena kelas besar atau siswa banyak.

Tabel 21 Deskripsi Kategori Sub Konsep Suasana Kerja $\left(\mathrm{X}_{2.2}\right)$ Indikator Empirik Kurangnya Fasilitas yang Dibutuhkan dalam Mengajar

\begin{tabular}{|c|c|c|}
\hline Tingkat Stres & $\mathbf{f}$ & Prosentase (\%) \\
\hline Tidak stres & 16 & $13,68 \%$ \\
\hline Lemah & 25 & $21,37 \%$ \\
\hline Sedang & 21 & $17,95 \%$ \\
\hline Kuat & 12 & $10,25 \%$ \\
\hline Sangat Kuat & 43 & $36,75 \%$ \\
\hline Jumlah & 117 & $100 \%$ \\
\hline
\end{tabular}

bahwa pada umumnya $(65,65 \%)$ guru menyatakan 'stres sedang' sampai "stres sangat kuat " karena kurangnya fasilitas yang dibutuhkan dalam mengajar.

Tabel 22 Deskripsi Kategori Sub Konsep Suasana

Kerja $\left(\mathrm{X}_{2.2}\right)$ Indikator Empirik Kurangnya

Hukuman yang Dikenakan pada Siswa yang Berkaitan dengan Disiplin

\begin{tabular}{|c|c|c|}
\hline Tingkat Stres & f & Prosentase (\%) \\
\hline Tidak stres & 35 & $29,92 \%$ \\
\hline Lemah & 24 & $20,51 \%$ \\
\hline Sedang & 42 & $35,90 \%$ \\
\hline Kuat & 9 & $7,69 \%$ \\
\hline Sangat Kuat & 7 & $5,98 \%$ \\
\hline Jumlah & 117 & $100 \%$ \\
\hline
\end{tabular}

bahwa pada umumnya $(86,33 \%)$ guru menyatakan 'tidak mengalami' sampai "stres sedang" karena kurangnya hukuman yang dikenakan pada siswa yang berkaitan dengan disiplin.

Tabel 23 Deskripsi Kategori Sub Konsep Suasana Kerja $\left(\mathrm{X}_{2.2}\right)$ Indikator Empirik Kurangnya Diskusi

\begin{tabular}{lcc}
\multicolumn{3}{c}{ Bermakna } \\
\hline \multicolumn{1}{c}{ Tingkat Stres } & f & Prosentase (\%) \\
\hline Tidak stres & 10 & $8,55 \%$ \\
Lemah & 51 & $43.58 \%$ \\
Sedang & 22 & $18,80 \%$ \\
Kuat & 20 & $17,09 \%$ \\
Sangat Kuat & 14 & $11,97 \%$ \\
\hline \multicolumn{1}{r}{ Jumlah } & 117 & $100 \%$ \\
\hline Pada & Tabel 23 & menunjukkan \\
bahwa pada & umumnya (70,93\%) guru \\
menyatakan & 'tidak mengalami stres'
\end{tabular}

sampai 'stres sedang' karena kurangnya diskusi bermakna.

Tabel 24 Deskripsi Kategori Sub Konsep Suasana Kerja $\left(\mathrm{X}_{2.2}\right)$ Indikator Empirik Sikap Guru Lain yang Tidak Hangat

\begin{tabular}{|c|c|c|}
\hline Tingkat Stres & f & Prosentase (\%) \\
\hline Tidak stres & 20 & $17,09 \%$ \\
\hline Lemah & 45 & $38,47 \%$ \\
\hline Sedang & 31 & $26,50 \%$ \\
\hline Kuat & 15 & $12,82 \%$ \\
\hline Sangat Kuat & 6 & $5,12 \%$ \\
\hline Jumlah & 117 & $100 \%$ \\
\hline
\end{tabular}

bahwa pada umumnya $(82,06 \%)$ guru menyatakan 'tidak mengalami stres' sampai 'stres sedang' karena kurangnya Sikap guru lain yang tidak hangat.

\section{Pembahasan}

Kebahagiaan tidak dapat dipastikan ada peningkatan skor atau penurunan skor. Bakker (2007) menggunakan Teachers Stres Survey (TSS) yang melihat beberapa faktor yaitu: perilaku kepala sekolah, perlakuan buruk orang tua dan murid, kurangnya relasi dengan rekan kerja, keikut sertaan guru dalam pengambilan keputusan, perkembangan profesi keguruan, status profesional seorang guru. Kesamaan hasil penelitian dapat disebabkan karena ada beberapa aspek yang sama diukur juga dalam penelitian ini walaupun instrumen yang digunakan berbeda.

Hubungan yang tidak signifikan antara stress dengan kebahagiaan guru pendidikan agama di kota Ambon, juga terlihat pada analisis deskriptif dalam Tabel 8 yang menjelaskan bahwa guru pendidikan agama di kota Ambon berada pada kategori stres "rendah" dan kebahagiaan pada kategori "sedang'. Namun dalam analisis item pada masingmasing sub konsep ditemukan bahwa tingkat stress pada kategori "sedang" 
tersebut disebabkan karena guru mengalami tekanan dalam beberapa hal yaitu kenakalan siswa, guru merasa kurang dihargai, beban kerja yang tinggi, serta perubahan kebijakan pendidikan yang dilakukan oleh pemerintah.

Penelitian ini tidak sejalan dengan kajian Anitawidanti (2010) yang menemukan ada hubungan negatif dan signifikan antara stres kerja dengan kebahagiaan. Responden yang di teliti dalam penelitian Anitawidanti (2010) adalah 260 orang karyawan dengan menggunakan kuesioner peran organisasi yang dikembangkan oleh Organizational Role Stres manual yang mengukur 4 faktor yaitu; Peran individu dalam organisasi, tuntutan tugas, hubungan dalam organisasi, dan faktor luar organisasi. Instrumen ini biasa digunakan dalam dunia industri atau bisnis.

\section{Hubungan Stres Guru $\left(\mathbf{X}_{2}\right)$ dengan Kebahagiaan (Y)}

Dari hasil uji korelasi sebagaimana ditunjukkan pada Tabel 4.10 bahwa ada hubungan negatif dan tidak signifikan antara stres guru dengan kebahagiaan guru pendidikan agama sekolah menengah di kota Ambon. Hal ini ditunjukkan dengan koefisien korelasi sebesar $-0,187$ dengan $p=0,051>0,05$. Berdasarkan hasil analisis korelasi antara empat sub konsep dengan variabel Kebahagiaan (Y) ditemukan bahwa sub konsep perilaku peserta didik $\left(\mathrm{X}_{2.1}\right)$, Tekanan waktu $\left(\mathrm{X}_{2.3}\right)$ dan Etos Kerja $\left(\mathrm{X}_{2.4}\right)$ tidak memiliki hubungan signifikan dengan arah hubungan negatif. Hanya sub konsep Suasana kerja/pekerjaan $\left(\mathrm{X}_{2.2}\right)$ yang memiliki hubungan negatif dan signifikan dengan koefisien korelasi -
$0,212^{* *}$ dan $p=0,011<0,05$. Ini berarti bahwa jika skor sub konsep suasana kerja/ pekerjaan $\left(\mathrm{X}_{2.2}\right)$ meningkat, maka skor kebahagiaan turun dan jika skor sub konsep suasana kerja turun maka skor kebahagiaan naik. Setelah dilakukan analisis yang dilakukan terhadap masingmasing indikator empirik dalam sub konsep suasana kerja/ Pekerjaan berdasarkan jawaban responden, ada 3 faktor yang menjadi penyebab stres guru dalam penelitian ini yaitu kurangnya peluang naik pangkat dan golongan $(87,18 \%)$ pada item 15 , sarana mengajar yang tidak memadai $(76,93 \%)$ pada item 17 dan kurangnya fasilitas yang dibutuhkan dalam mengajar $(65,65 \%)$ pada item 22 .

Hasil penelitian ini sejalan dengan kajian Bakker (2007) yang menyatakan ada hubungan negatif dan tidak signifikan antara stres guru dengan kebahagiaan. Artinya bila skor stress meningkat maka skor kebahagiaan tidak dapat dipastikan ada peningkatan skor atau penurunan. Bakker (2007) menggunakan Teachers Stres Survey (TSS) yang melihat beberapa faktor yaitu: perilaku kepala sekolah, perlakuan buruk orang tua dan murid, kurangnya relasi dengan rekan kerja, keikut sertaan guru dalam pengambilan keputusan, perkembangan profesi keguruan, status profesional seorang guru. Kesamaan hasil penelitian dapat disebabkan karena ada beberapa aspek yang sama diukur juga dalam penelitian ini walaupun instrumen yang digunakan berbeda.

Hubungan yang tidak signifikan antara stress dengan kebahagiaan guru pendidikan agama di kota Ambon, juga terlihat pada analisis deskriptif dalam 
Tabel 8 yang menjelaskan bahwa guru pendidikan agama di kota Ambon berada pada kategori stres "rendah" dan kebahagiaan pada kategori "sedang'. Namun dalam analisis item pada masingmasing sub konsep ditemukan bahwa tingkat stress pada kategori "sedang" tersebut disebabkan karena guru mengalami tekanan dalam beberapa hal yaitu kenakalan siswa, guru merasa kurang dihargai, beban kerja yang tinggi, serta perubahan kebijakan pendidikan yang dilakukan oleh pemerintah.

Penelitian ini tidak sejalan dengan kajian Anitawidanti (2010) yang menemukan ada hubungan negatif dan signifikan antara stress kerja dengan kebahagiaan. Responden yang di teliti dalam penelitian Anitawidanti (2010) adalah 260 orang karyawan dengan menggunakan kuesioner peran organisasi yang dikembangkan oleh Organizational Role Stres manual yang mengukur 4 faktor yaitu; Peran individu dalam organisasi, tuntutan tugas, hubungan dalam organisasi, dan faktor luar organisasi. Instrumen ini biasa biasa digunakan dalam dunia industri atau bisnis

\section{SIMPULAN}

Berdasarkan hasil analisis dapat disimpulkan temuan penelitian ini sebagai berikut:

1. Ada hubungan yang positif dan signifikan antara kepuasan kerja guru dengan kebahagiaan guru pendidikan agama sekolah menengah di kota Ambon;

2. Ada hubungan negatif dan tidak signifikan antara stres guru dengan kebahagiaan guru pendidikan agama sekolah menengah di kota Ambon. Hasil analisis korelasi sub konsep menunjukkan bahwa ada hubungan negatif dan signifikan antara sub konsep suasana kerja/pekerjaan $\left(\mathrm{X}_{2.2}\right)$ dengan kebahagiaan (Y) sedangkan untuk sub konsep perilaku peserta didik $\left(\mathrm{X}_{2.1}\right)$, tekanan waktu $\left(\mathrm{X}_{2.3}\right)$ dan etos kerja $\left(\mathrm{X}_{2.4}\right)$ ditemukan ada hubungan negatif dan tidak signifikan.

\section{DAFTAR PUSTAKA}

Al-banjari,R.R. 2009. The Route of Happiness, Yogjakarta: Diva Press.

Ali, M. 1985. Penelitian Kependidikan, Prosedur dan Strategi. Bandung: Angkasa.

Alunpah, Tutje Mery. 2005. Hubungan tipe kepribadian, stress guru dengan kinerja guru SMP Negeri di Kota Soe, Salatiga: Program Pascasarjana Manajemen Pendidikan UKSW.

Anitawidanti, H. 2010. Analisis Hubungan Antara Stres Kerja Dengan Kepuasan Kerja Karyawan Berdasarkan Gender Studi Pada Pt Transindo Surya Sarana Semarang, Fakultas Ekonomi Universitas Diponegoro Semarang. http://eprints. undip.ac.id/22995/1/ SKRIPSI_STRES_KERJA_VS_KEP UASAN_KERJA.pdf.

Arikunto, S. 1998. Prosedur penelitian suatu pendekatan praktek, Yogyakarta : Rineka cipta.

Bakker D. 2007. Stress and work engagement among teachers, Journal of School Psychology.http://www. fss.uu.nl/ sop/Schaufeli/246.pdf . 
Bertens, K. 1999. Sejarah Filsafat Yunani: Dari Thales ke Aristoteles. Yogyakarta: Kanisius.

Carr, A. 2004. Positive Psychology The Science of Happiness and Human Strength. NewYork: Brunner Routledge.

http://www.google.com/books?hl=id\&lr= $\& i d=g u 3 V 9 K y s \_Q E C \& o i=f n d \& p g$ $=P A 1 \&$ ots $=$ Fealq - EgRv\&sig $=$ LWbDWastXYM3jw-

$M A G P 4 V P x X j e E \# v=$ onepage $\& q \& f$ $=$ false.

Chao, S. (1995). A study on occupational stress among teachers in primary and secondary schools. Unpublished paper of a directed research project (conversion), Lingnan College, Hong Kong (http://epm.sagepub. com/ content/66/1/172).

Csikszentmihalyi, M. 1990. Flow: The Psychology of Optimal Experience. New York, NY. http://www.pursuitof-happiness.org/historyofhappiness/mihaly csikszentmihalyi/

Dahlan, D. 2007. Analisa faktor-faktor yang mempengaruhi kepuasan kerja guru (studi deskriptif analitik pada SMA Negeri se-kabupaten Buleleng, ) http://file.upi. edu/Direktori/FPEB/PRODI._EKO NOMI_DAN_KOPERASI/1957120 51982031-DADANG_DAHLAN/ Hasil_Penelitian_3.pdf.

George, D. \& Mallery, P.1999. SPSS/PC/+ Step By Step, A Simple Guide and Reference, Beimont: Wadsworth Publishing Co.

Holle, P. 2009. Hubungan perilaku kepemimpinan kepala sekolah, iklim sekolah dan komitmen guru dengan semangat kerja guru SD Swasta di Kota

Ambonhttp://www.google.co.id/sear ch $? h l=i d \&$ source $=h p \& b i w=1024 \&$ bih $=482 \& q=$ Penelitian + Holle $+(20$ 09) + pada $+36+S D+$ Swasta $+d i+k o t$ $a+$ Ambon+dengan+populasi $+205+$ orang+guru+dan+sampel+sebanya $k+127+$ orang + guru $+\& b t n G=$ Penel usuran + Google \&aq $=f \& a q i=\& a q l=$ $\& o q=$

Hughes. V. 2006.Teacher evaluation practices and teacher job satisfaction, A Dissertation presented to the Faculty of the Graduate School University of Missouri-Columbia.

Joltuwu. J.C. 2009.Hubungan penenyesuaian diri dan self-efficacy dengan indeks prestasi kumulatif mahasiswa fakultas filsafat UKIM Tahun 2007/2008. Salatiga: program Pascasarjana Magister Manajemen Pendidik-an UKSW.

Kyriacou dan Chien. 2004.Teacher stress in Taiwanese primary schoolshttp://ojs.ml.unisa.edu.au/ind ex. php/EDEQ/article/view/511.

Lester P. E. 1982. Teacher Job Satisfaction Questionnaire (TJSQ). Manuscrito não-publicado. Long. http://epm.

sagepub.com/content/47/1/223.abstr act.

1987. Development and factor analysis of the Teacher Job Satisfaction Questionnaire (TJSQ). Educational and Psychological Measurement, 47 (1), 223-233.

Loekmono, J.T. 2005. "Tingkat dan faktor-faktor penyebab stress guru 
di kota waingapu sumba Timur, Jurnal Kependidikan: Desiderata. Vol 6 no 2.1-27. 1999. Stres Guru. Salatiga: PPPK, UKSW.

Ouyang dan Paprock.2009. Job satisfaction: Kepuasan Pekerjaan Guru dan retensi: Sebuah Studi perbandingan antara Amerika dan Cina.http://ujianbasuki.Blogspot.com/

OwensRobert G. 2005 Organizational behavior in education. Fifth edition, United state : Allyn and Bacon.

Piccolo, Takahashi, Watanabe. 2005. Core self-evaluations in Japan: relative effects on job satisfaction, life satisfaction, and happiness.http://www.mendeley. com/research/core-selfevaluationsjapan-relative-effects-jobsatisfaction-life-satisfactionhappiness/.

Radityo C. 2008. hubungan antara tingkat stress kerja guru dan tingkat komunikasi interpersonal gurusiswa dengan kenerja guru SMK Kristen 2 Kalten. Salatiga: Program Pascasarjana Magister Manajemen Pendidik-an UKSW.

Seligman, Martin. 2002. Authentic Happiness. New York,NY: Free Press. http://www.thefreelibrary.com/ Seligman, + M. + E. + P. $+(2002) .+$ Aut hentic + Happiness $:+$ Using + the $+\mathrm{Ne}$ w...-a0150850221 , dan Peterson. 2005. Authentic Happiness: Menciptakan kebahagiaan dengan psikologi positif. Bandung: Mizan.

Sugiyono. 2011. Statistik untuk Penelitian. Bandung: Alfabeta. Cet18.

Suseno.M.F.1998. 13 Model Pendekatan Etika. Yogyakarta: Kanisius.

The professional teacher union of Hongkong. 1995. The problem of teacher stress was a great concern in Hong Kong. As in many media also mention that nowadays teachers are suffers from great pressure.

http://www.ukessays.com/essays/tea ching/teacher-stress.php.

Veenhoven R. 2001. Quality of Life and Happiness. 'Salute e qualità dell vida, pp 67-95 diunduh pada 19 Mei 2009

dari www2.eur.nl/fsw/research/veenhove n/ Pub2000s/2001e-full.pdf.

Yayik N. 2011. Hubungan persepsi guru terhadap iklim kelas dengan kepuasan kerja guru SMK Farmasi Medan, Universitas sumatera utara. http://repository. usu.ac.id/handle/123456789/22025 